I Universidade Federal do Rio Grande do Sul (UFRGS), Programa de Pós-Graduação em Antropologia Social, Porto Alegre, RS, Brasil steil.carlosalberto@gmail.com https://orcid.org/0000-0002-4713-0772

\title{
PADRE CÍCERO: RECONCILIAÇÃO E MODERNIDADE
}

Neste artigo revisitamos a literatura sobre as controvérsias eclesiais e políticas em torno do padre Cícero Romão Batista, que marcou de forma indelével a história do Brasil, propondo uma interpretação a partir da chave da reconciliação. ${ }^{\mathrm{I}}$ Ao mesmo tempo, queremos colocar-nos em sintonia com os milhares de romeiros que com seu peregrinar pelo sertão nordestino continuam trazendo-o de volta à vida. A trajetória do santo nacional mais popular, como mostra a extensa literatura sobre o catolicismo e a política no país, desdobrou-se em inúmeros eventos, que mobilizaram fortes paixões desde a segunda metade do século XIX até os dias de hoje. Vistos numa perspectiva história, os acontecimentos do Juazeiro estão distantes de qualquer intento de localizá-los num espaço local ou isolado. Ao contrário, como bem mostrou Ralph Della Cava (I976: 20),

este movimento religioso-popular originou-se e desenvolveu-se dentro de um contexto social definido pelas estruturas dominantes em âmbito mundial e nacional. Para sermos mais precisos, o movimento religioso-popular de Juazeiro afetou e foi afetado: (I) pela instituição eclesiástica internacional, a Igreja Católica Apostólica Romana; (2) pelo sistema político nacional do Brasil imperial e republicano; e (3) por uma economia nacional e internacional em mudança.

Repensar esse movimento, no contexto do século XXI, é o desafio a que nos propomos, tendo como ponto de ancoragem o trabalho realizado na Comissão de Reabilitação Histórica do Padre Cícero, criada pela diocese do Crato no início dos anos 2000, bem como o acompanhamento das ações do Vaticano que culminaram com a reconciliação oficial da Igreja católica com o padre Cícero, 
ocorrida em 20I5, por meio da anulação das sanções que lhe foram impostas pela hierarquia católica em I892. ${ }^{2}$ Como mostram esses desdobramentos, o movimento de Juazeiro não foi interrompido pelos decretos eclesiásticos que tentaram extirpá-lo da cena pública e apagá-lo da memória social nem pelas interpretações dos jornalistas e cientistas sociais que pretendiam relegá-lo a um passado que seria totalmente superado pelo projeto político modernizador e iluminista. Ao contrário, entendemos que ele está vivo e presente na atualidade, abrindo a possibilidade de novas interpretações.

Ao retomar a análise do movimento de Juazeiro, buscamos privilegiar uma visão de processo, aberta à ideia de invenção e de improvisação constantes. Ao mesmo tempo, procuramos pôr em xeque algumas interpretações sociológicas e teológicas que deram origem a uma série de categorias, forjadas no âmbito das ciências sociais, que, embora tivessem o propósito de oferecer um marco compreensivo para o movimento, foram usadas, social e politicamente, como categorias de acusação, discriminação e menosprezo em relação ao sertão e aos romeiros. Na contramão dessas interpretações, que foram hegemônicas no meio intelectual brasileiro, refletimos aqui sobre o sentido político e social da reconciliação.

O percurso deste texto inicia-se com algumas breves considerações teológicas sobre o lugar da reconciliação no pensamento bíblico, seguidas da interpretação filosófico-política de Hannah Arendt sobre o perdão. Essa incursão pela teologia e pela filosofia permite-nos perceber, para além do campo das ciências sociais, outros fios interpretativos que tecem a trama do que vem sendo vivido como uma experiência de reconciliação. Feito isso, passamos a seguir os fios que vêm guiando as ciências sociais na compreensão da reconciliação nos espaços eclesial e político brasileiros, tendo como referência os eventos de Juazeiro. Nesse sentido, destacamos dois movimentos: um, pensado a partir da perspectiva da Igreja católica, denominado romanizador; e outro, referido à sociedade nacional inclusiva, chamado de modernizador. Como mostramos, esses dois movimentos são linhas que se entrelaçam, mantendo, contudo, as suas respectivas especificidades. No passo seguinte, analisamos os desdobramentos da prática de reconciliação na vida do padre Cícero, que se expressa em sua luta por incluir os pobres na narrativa da nação. O percurso do texto termina com a interpretação de uma cena pública, narrada pelo jornalista e educador Lourenço Filho, de seu encontro com o padre Cícero, no Juazeiro.

\section{A RECONCILIAÇÃo À LUZ DA TEOLOGIA BÍBLICA DE JOAHANNES BAUER}

O exercício da reconciliação não é prerrogativa de uma instituição nem de uma pessoa, mas envolve indistintamente todos aqueles que fazem parte de um determinado grupo social ou que pertencem a um movimento. Com o intuito de acessar algumas camadas de sentidos que conferem densidade à experiência da reconciliação, fazemos uma breve incursão às referências teológicas so- 
bre o seu sentido bíblico. Nessa incursão, guiamo-nos pelas indicações do Dicionário bíblico-teológico, editado por Joahannes Bauer (2000: 357-358).

A primeira indicação é a de que a reconciliação pertence fundamentalmente à tradição neotestamentária. O Antigo Testamento não desenvolveu uma teologia da reconciliação. Seu solo de origem, portanto, é a vivência das primeiras comunidades cristãs, ao qual temos acesso por meio das cartas paulinas (Rm 5, IOS; I I, 5; 2 Cor 5, I8-20; Ef. 2, I6; Cl I, 20s). A segunda indicação é a de que a experiência da reconciliação, entre os primeiros cristãos, tinha um caráter eminentemente escatológico. Ou seja, seu sentido primordial, que engloba os demais, é o da reconciliação com o universo. No seu horizonte, o Juízo Final e a restauração da Nova Jerusalém apresentam-se como prelúdio de novos céus e de nova terra. Os outros dois sentidos: o eclesiológico e o antropológico, estão subordinados ao primeiro. Disso decorre o fato de que a reconciliação, em qualquer nível em que ela aconteça, traz consigo a ideia de um fim iminente para o mundo, ao mesmo tempo em que reitera o dogma da nova vinda de Cristo.

Esse sentido escatológico da reconciliação impregna a vida e a prática dos romeiros do padre Cícero, para os quais o Juízo Final e a Nova Jerusalém deveriam se realizar em Juazeiro. E, extrapolando o contexto do Juazeiro, podemos afirmar, como o fizemos em relação a Bom Jesus da Lapa, que a reconciliação é o fio mestre na tessitura da cultura bíblico-católica que conforma o modo de habitar e o estilo de vida dos peregrinos do sertão (Steil, I996: I5I). Observa-se, assim, uma linha de continuidade entre a escatologia bíblica e a visão de mundo dos sertanejos. Para ambas, a reconciliação se apresenta como um caminho aberto, englobando a vida e a morte num processo contínuo, que envolve a pessoa em sua relação com os outros seres humanos e com o universo. Imersa no mundo material e social, a escatologia apresenta-se como uma linha de fuga que permite experimentar a vida como um processo sem fim. É, enquanto peregrinos, caminhando neste mundo, ameaçados pelas catástrofes anunciadas, mas, ao mesmo tempo, movidos pela esperança, que os romeiros do sertão encontrarão a reconciliação com Deus e com o universo.

Ao imprimir movimento à reconciliação, a escatologia instaura o devir no centro da vida. A morte, nessa perspectiva, não é o fim, mas apenas mais um acontecer no movimento da vida. À luz da escatologia, aqueles que afirmamos ter morrido, que já não estão mais aqui - Jesus, Nossa Senhora, os santos e o próprio padre Cícero - para os romeiros e devotos, continuam vivos e presentes, uma vez que são pontos de conexão entre vivos e mortos. A reconciliação, portanto, estende-se para as múltiplas dimensões da Igreja, configurando e reafirmando a crença na comunhão dos santos. Essa, por sua vez, engloba os peregrinos, que habitam a terra; os santos, que vivem na eternidade; e as almas do purgatório, que pagam as penas pelos resíduos desagregadores de suas ações, realizadas neste mundo, quando aqui estiveram, enquanto aguardam a reconciliação final, que as introduzirá no convívio dos santos. 


\section{A RECONCILIAÇÃo À LUZ dA FILOSOFIA POLÍTICA DE HANNAH ARENDT}

Passamos, agora, a considerar a reconciliação, tomando como referência a reflexão de Hannah Arendt (I989) sobre o perdão, em seu livro A condição humana, publicado originalmente em I958. Em consonância com o argumento teológico, que desenvolvemos, Arendt(i989: 250) afirma que "o descobridor do papel do perdão na esfera dos negócios humanos foi Jesus de Nazaré". Partindo da premissa de que existimos atados numa teia de relações que produzem atritos e conflitos constantes, Hannah Arendt afirma que o perdão é indispensável para libertar e desobrigar o ser humano das consequências desagregadoras de suas ações. Ou seja, o perdão é condição para a liberdade. Nas suas palavras, "somente através dessa mútua e constante desobrigação [produzida pelo perdão], os seres humanos podem ser agentes livres" (Arendt, I989: 252). O perdão é, portanto, o oposto da vingança, a qual atua como "re-ação". Ao contrário da vingança, o ato de perdoar jamais pode ser previsto. Ele acontece de modo inesperado e, embora seja reação, conserva algo do caráter original da ação. Em outras palavras, o perdão é a única reação que não apenas "re-age", mas age inesperadamente, sem ser condicionado pelo ato que a provocou. E a consequência dessa ação inesperada faz com que o perdão liberte tanto o que perdoa quanto o que é perdoado.

Hannah Arendt prossegue sua reflexão, chamando a atenção para a dimensão humana da reconciliação. E cita a formulação de Jesus, segundo a qual, a iniciativa do perdão é sempre do ser humano. O evangelho afirma que se deve perdoar não porque Deus perdoa, mas, sim, que Deus perdoará "se cada um de vós, no íntimo dos vossos corações, perdoar o outro" (Mt I8, 35 e Mc I I, 25). O ato de perdoar consiste, portanto, em mediar os conflitos diários, as pequenas ofensas, os mal-entendidos e os sofrimentos não intencionais que decorrem, como resíduos, da ação humana. Sem a reconciliação, a vida social se tornaria impraticável. Assim, é no nível do convívio cotidiano que a reconciliação ocorre. Ela liberta tanto aquele que ofende quanto o ofendido do inexorável processo da ação.

Outro aspecto a resgatar do pensamento de Arendt diz respeito à relação da reconciliação com o amor. Aqui, segundo a autora, o evangelho é claro: "Perdoados lhe serão os seus muitos pecados, porque amou muito; mas ao que menos se perdoa, menos ama" (Lc 7, 47). Embora esteja referido sobretudo ao universo das relações pessoais, o amor se traduz, no âmbito político, segundo Arendt, por respeito. E, respaldada em Aristóteles, ela define o respeito (philia politike) "como uma espécie de amizade sem intimidade [...] nutrida a distância" (Arendt, I989: 255). O problema dos tempos modernos, prossegue Arendt (I 989: 255), é que "o respeito está restrito ao que se admira ou se preza". No entanto, argumenta a autora, na vida política e social, o respeito pelo outro, enquanto tradução do amor, é condição indispensável para que possa haver reconciliação. Enfim, a existência de um ambiente amoroso torna-se indispensável para o 
exercício do perdão e para a prática da reconciliação na vida cotidiana. Sem esse ambiente, em vez da reconciliação, teremos a intolerância e o desprezo pelo outro.

\section{A MODERNIZAÇÃO LIBERAL E A ROMANIZAÇÃO: DOIS PROJETOS NA CON- TRAMÃO DA RECONCILIAÇÃO}

Após esse rápido détour pelos campos da teologia e da filosofia, tomamos o caminho das ciências sociais em busca de um aprofundamento dos sentidos da reconciliação na vida social e política. Assim, ao lançar um olhar sobre o final do século XIX e início do XX, período em que viveu padre Cícero, vamos perceber que esse momento histórico esteve marcado por uma profunda ruptura cultural, produzida pelo projeto de modernização que se impôs, de fora para dentro, tanto no âmbito da sociedade brasileira quanto da Igreja católica. Deslumbradas pela crença no progresso, as elites econômicas e políticas, secundadas pelos intelectuais e pelo clero ultramontano, reinterpretaram as relações sociais de complementariedade da sociedade agrária e tradicional - fundadas sobre os estatutos do compadrio, do arrendamento de terras e do faccionalismo político - na chave da ideologia moderna, criando uma divisão irreconciliável entre as elites nacionais escolarizadas e o povo pobre e iletrado dos sertões.

Para os modernos, já não se trata, portanto, de promover a reconciliação entre ricos e pobres ou, ainda, entre peregrinos e convertidos, mas de erradicar as massas ignorantes e supersticiosas, combatendo, pela violência simbólica, os valores de sua cultura e religiosidade e, se preciso for, pela força militar, seus insurgentes, como aconteceu nas guerras de Canudos e do Contestado. O projeto moderno liberal, coloca-se, então, na contramão da reconciliação e do perdão. Ou seja, tanto as elites quanto o clero reformador posicionam-se externamente em relação ao povo: sua cultura, tradição e religiosidade. Ambos voltam o olhar para o futuro idealizado dos países desenvolvidos, onde se poderia ver realizadas as promessas da modernidade, e dão as costas para o povo dos sertões. ${ }^{3}$

A concepção de nação que se forja a partir desse ideário enseja uma prática social, política e eclesial que internaliza e institui a divisão entre uma minoria iluminada, que se vê como a vanguarda de um futuro a ser construído, e uma maioria não escolarizada, que precisa ser erradicada da vida social e política do país. Como mostramos em seguida, essa concepção, incorporada pela teoria social, acaba sendo justificada pela pena de seus intelectuais, que reforçam e legitimam a visão dualista de um país cindido. Esse dualismo que, por sua vez, não é inocente, continua operando ideologicamente na economia, na política e no campo religioso. E, apesar dos avanços materiais que possam ser contabilizados, ao longo deste século e meio de implementação do projeto moderno, esse dualismo permanece, até os dias de hoje, disseminando a discriminação e o desprezo das elites pelos pobres e por suas tradições, reiterando o sentimento de que tudo que é brasileiro é ruim. 
No âmbito eclesial, o dualismo instituiu a divisão entre o catolicismo popular tradicional, aqui implantado com a conquista portuguesa sobre o território indígena, e o catolicismo romano clerical, que resultou do movimento ultramontano de reforma institucional e burocrática, de ocorrência no catolicismo mundial. Esse movimento, que ficou conhecido como romanização, inicia-se na segunda metade do século XIX e se estende até os dias de hoje. ${ }^{4}$ À luz da romanização, as práticas devocionais populares com suas rezas, festas e folias são classificadas como supersticiosas e interpretadas como um legado histórico negativo a ser superado pela catequese e a disciplina moral. Assim, embora discordassem em relação aos princípios fundantes da vida social e ao modelo de sociedade a ser implantado, o projeto moderno liberal das elites brasileiras e o movimento eclesial reformador convergiram em termos político-programáticos e estabeleceram uma aliança estratégica contra a cultura e o catolicismo populares, vistos como obstáculos no caminho da modernização política e da ordem moral. Ou seja, além dos conflitos que marcaram as relações entre a Igreja católica e o Estado no reinado de Pedro II, que engendraram a questão religiosa, 5 após a proclamação da república, observa-se uma convergência de interesses, que se expressa no apoio das elites modernas laicas e do clero romanizador ao uso da força militar contra os movimentos populares milenaristas que eclodiram nas guerras de Canudos e do Contestado. ${ }^{6}$

$\mathrm{Na}$ contramão do consenso em torno de um projeto que mira o futuro e despreza o presente, permitam-me citar a voz dissonante de Lévi-Strauss que, em I944, escreveu uma resenha de Os Sertões, de Euclides da Cunha, na revista American Anthropologist. Nesse texto, ele conclama os intelectuais brasileiros a não recusar, em nome da modernidade, aquilo que seria autêntico e estruturante da sua cultura. O grande mérito de Euclides da Cunha, segundo Lévi-Strauss (I944: 396), teria sido o de "trazer a elite brasileira de volta à realidade" em vez de "tentar escapar do seu próprio destino nacional e simular sofisticação". Na sua avaliação, Euclides da Cunha teria "se recusado a ser um aprendiz infantil dos mestres europeus" e demonstrado que, "para o Brasil existir, seus aspectos primitivos, seus pontos mais feios deveriam ser aceitos; não para deles se envergonhar, mas para deles se cuidar e amar com a maior paciência e compreensão". Segundo Lévi-Strauss, Euclides fez o que era preciso: "lembrar o povo brasileiro que as conquistas da civilização industrial não são tão formidáveis e incontestáveis que ele devesse tentar esquecer, em vez de se orgulhar, daquelas fontes virgens da natureza e da humanidade, nas quais, entre todas as nações, ele pode se fiar para a construção de um futuro melhor".

\section{A RECONCILIAÇÃO COM OS POBRES DO SERTÃo}

O argumento que desenvolvemos aqui é que padre Cícero jamais se envergonhou do "primitivismo" ou da cultura popular dos pobres do sertão, mas, ao contrário, nela esteve inserido de uma forma plena para "cuidar de e amar com a 
maior paciência e compreensão" aqueles que eram desprezados pelos intelectuais e pelo clero reformador. Sua posição, diante da modernidade, não desprezava os benefícios que advinham do progresso técnico e social, implementados pelo Estado, nem da moralização dos costumes, promovida pela Igreja católica. ${ }^{7}$ O que o distinguia dos intelectuais liberais e do clero romanizador era sua inconteste convicção de que tanto o projeto político quanto o eclesial deveriam incluir a contribuição e participação dos pobres. Ou seja, qualquer projeto de modernização ou reforma religiosa, na visão de padre Cícero, deveria partir da realidade do povo e ser tecido com os fios da sua cultura e religiosidade. Sua atitude, portanto, não era de recusa da modernidade ou da reforma do catolicismo, mas de reconciliação entre tradição e modernidade a partir de seu profundo respeito e amor aos pobres.

Um olhar retrospectivo sobre a trajetória do padre Cícero deixa transparecer um certo desencaixe em relação ao modelo clerical que a romanização procurava incutir nos candidatos ao sacerdócio. Esse desencaixe aparece, por exemplo, na avaliação do superior do seminário de Fortaleza, padre Pierre Chevalier, "que argumentava ser o seminarista Cícero, em muitos casos, demasiadamente místico, cabeçudo e, por vezes, audacioso em matéria doutrinária para poder ser ordenado" (Della Cava, I976: 43). No entanto, em vez de interpretar esse posicionamento como um problema de desvio de comportamento, talvez pudéssemos ver aí um primeiro indício da sua recusa a submeter-se incondicionalmente ao projeto romanizador.

Embora tenha sido formado no rigor de um seminário ultramontano, padre Cícero recusa-se a assumir uma posição de externalidade em relação ao catolicismo popular. O efeito da romanização sobre sua formação foi nuançado pela admiração que ele nutria pela figura do padre Ibiapina (I806-I883), com quem padre Cícero tinha profunda identificação. O ardor missionário e o exemplo de vida dedicada aos pobres, que pautaram a vida de Ibiapina, tiveram grande influência sobre o estilo pastoral que conformou a atuação do Padre Cícero ao longo de toda a sua vida. O exemplo de Ibiapina deixou marcas profundas no catolicismo popular dos sertões e é referido muitas vezes por padre Cícero, embora a hierarquia eclesiástica da época tenha contestado seu trabalho. ${ }^{8}$

Foi a inspiração de Ibiapina e sua profunda empatia para com os pobres dos sertões que determinou a escolha de padre Cícero por Juazeiro, como local de trabalho. Primeiramente, é preciso lembrar que sua ida para Juazeiro foi uma decisão pessoal, fundamentada sobre uma experiência onírica, como veremos em seguida, e não por uma decisão ou nomeação dos superiores, aos quais devia obediência. Uma forma de procedimento que, ao mesmo tempo em que revela o viés místico de sua personalidade, também mostra sua força e coragem de posicionar-se ao lado dos pobres, desafiando o poder e a autoridade da Igreja católica. Esta decisão pessoal - que será interpretada pela hierarquia como um ato de desobediência - torna-se particularmente contundente no contexto de 
confronto aberto entre o clero reformador e os agentes do catolicismo tradicional. O relato do sonho, que respaldou sua escolha, narrado e repedido muitas vezes pelo próprio padre Cícero, é uma peça fundamental para se entender sua posição como mediador entre o catolicismo tradicional do povo do sertão, ao qual ele se sente ligado devido a suas raízes e origem familiar, e o catolicismo institucional e clerical, no qual foi formado. Vamos ao relato. ${ }^{9}$

Certa vez, ao anoitecer de um dia exaustivo, após ter passado horas a fio a confessar os homens do arraial, [Padre Cícero] atravessou, pesadamente, o pátio da capela, em direção ao prédio da pequenina escola onde estava provisoriamente alojado. Aí, no quarto contíguo à sala de aulas, caiu no sono e a visão fatal se revelou: I3 homens em vestes bíblicas entraram na escola e sentaram-se em volta da mesa do professor, numa disposição que lembrava a última Ceia, de Leonardo da Vinci. O padre sonhou, então, que acordava e levantava-se para espiar os visitantes sagrados, sem que estes o vissem. Nesse momento, os I2 apóstolos viraram-se para olhar o Mestre. (....). No momento em que o Cristo imaginário se levanta para dirigir a palavra a seus apóstolos, um bando de camponeses miseráveis entrou, de repente, na escola. Carregando seus parcos pertences em pequenas trouxas sobre os ombros, estavam os homens e as mulheres vestidos de farrapos, e as crianças nem isso tinham. Davam a impressão de serem de muito longe, de todos os recantos dos sertões nordestinos. [...]. Naquele momento ele [Cristo] apontou para os pobres e voltando-se, inesperadamente para o jovem sacerdote estarrecido, ordenou: 'E você, Padre Cícero, tome conta deles'. 'Com essa ordem', contou Padre Cícero a um amigo, anos depois, 'acordei e não vi mais nada; mas pensei um pouco e decidi, mesmo errado, a obedecer'. Meses depois, naquele mesmo ano, Padre Cícero juntou os poucos bens que tinha no Crato e mudou-se para Juazeiro, trazendo sua mãe e suas duas irmãs solteironas. Instalou-se numa pequena casa coberta de palha, defronte à Capela de Nossa Senhora das Dores, e começou sua vida de sacerdócio entre os pobres que lhe haviam sido confiados no sonho predestinado" (Della Cava, 1976: 26-27).

Padre Cícero expressa, nesse sonho, sob forma alegórica, como é próprio da linguagem onírica, sua decisão de trilhar o seu próprio caminho pastoral, de inserção junto aos pobres do sertão. Essa decisão, no entanto, não é repentina, como ele mesmo relata noutros testemunhos sobre sua missão em Juazeiro, mas havia sido amadurecida ao longo de sua formação presbiteral. E, se sua decisão é anterior, como acreditamos, a narrativa desse sonho foi fundamental para respaldar sua convicção de que Deus o chamava para uma missão especial. Ela, no entanto, está marcada pela dúvida, uma vez que a obediência ao chamado direto de Deus, "para viver com e cuidar dos miseráveis do sertão", seria interpretada como uma desobediência aos superiores. A referência a essa dúvida é explícita no texto: "Com essa ordem [afirma Padre Cícero], acordei e não vi mais nada; mas pensei um pouco e decidi, mesmo errado, a obedecer". Ou seja, padre Cícero decide seguir o chamado de Jesus, mesmo sabendo que esse seguimento seria tomado como uma atitude de desobediência pela hierarquia eclesiástica. O recurso ao sonho será usado, por ele, em outras situações de crise, para legitimar decisões que partem de sua consciência, mas que não se 
adequam à estratégia do projeto reformador. Sua fidelidade ao evangelho e a coerência com sua consciência - que o levam a desobedecer à instituição - jamais serão traídas por ele, ainda que lhe causem inúmeras atribulações pessoais e punições disciplinares ao longo de toda a sua vida.

O recurso à linguagem onírica para legitimar decisões não é estranho à experiência da vida cotidiana. Poderíamos mesmo dizer que é normal, para qualquer pessoa, crente ou não, receber mensagens ou ter uma visão em sonhos que tornam inteligíveis questões com que se debatem ou que aclaram situações em que é preciso tomar uma decisão conflitante. A linguagem onírica, portanto, não deve ser tomada como uma fuga do mundo real, mas, antes, como um impulso para a ação. É nesse horizonte que interpretamos a decisão do padre Cícero em seguir a missão evangélica que lhe fora atribuída por Jesus de "amar e cuidar dos pobres", mesmo tendo a consciência de que estaria cometendo uma desobediência. ${ }^{\text {Io }}$

As imagens, na visão onírica, não se situam num domínio separado da vida, mas são formas narrativas de elaborar a contradição entre o desejo e a realidade. É, acima de tudo, durante os sonhos, quando os limites entre a imaginação e a realidade ficam borrados e a linha que demarca a separação entre o desejo e o vivido se apaga, que acontece a abertura para aventura-se por caminhos não traçados de antemão e para enfrentar os desafios de uma escolha sem voltas. A narrativa do sonho inscreve-se, assim, num movimento contínuo da imaginação para a realidade e da realidade para a imaginação. O sonho introduz padre Cícero num cosmo em que o mito e a história se entrelaçam e tecem a trama do mundo vivido, inscrevendo e ambientando a narrativa bíblica no sertão. Ou seja, como vemos no relato transcrito, o quadro A Última Ceia é redesenhado pela presença dos retirantes que, com a crueza de sua miséria, adentram a cena onírica e misturam-se com os personagens bíblicos. Assim, ao trazer aqui o relato do sonho na experiência biográfica do padre Cícero não o fazemos com o intuito de elaborar uma interpretação psicanalítica, mas, sim, de mostrar como o caminho que ele trilha expressa um profundo desejo de empatia e comunhão com o povo do sertão e de respeito pela cultura e a religiosidade populares.

\section{AS CONTROVÉRSIAS EM TORNO DO MILAGRE}

O recurso ao sonho, para justificar a desobediência do padre Cícero à hierarquia, será acionado novamente na controvérsia que envolve o milagre da transformação da hóstia em sangue, envolvendo a beata Maria de Araújo. Sem entrar nas disputas teológicas e eclesiásticas do longo processo que o milagre desencadeou - detalhadamente analisado por Ralph Della Cava - nosso intuito aqui é apenas o de assinalar a atitude de reconciliação do padre Cícero diante da intransigência do bispo em exigir a retratação do clero ao reconhecimento de que o sangue que vertera na boca da beata, e que fora recolhido nos "paninhos", que se torna- 
ram objeto de veneração, possuísse qualquer teor de verdade. ${ }^{\text {II }}$ Em carta ao bispo, anexada à "petição de apelação", que fora enviada por cinco padres e 34 cidadãos da região do Cariri a dom Joaquim José Vieira, em julho de I89 I, padre Cícero, mais uma vez, recorre ao sonho para justificar sua recusa a retratar-se, a qual, estava ele ciente, seria tomada pelo bispo como um ato de desobediência. Sobre esse episódio, escreve Della Cava (I976: 64).

Padre Cícero justificou sua posição recorrendo a uma fonte de autoridade mais alta do que a de Dom Joaquim. Explicou solenemente que, durante três dias consecutivos, Cristo apareceu-lhe [em sonho] numa série de visões, revelando-lhe o significado dos acontecimentos de Juazeiro. "A vista de testemunhos desta ordem", perguntava Padre Cícero, "poderia eu deixar de crer e de afirmar que o sangue manifesto aqui nas sagradas formas é o Sangue de Jesus Cristo?”

A interpretação de Della Cava sobre a longa controvérsia, que teve o milagre como evento desencadeador, enfatiza os conflitos que emergem como divisores de águas entre os grupos envolvidos. Sua tese é que a disputa em torno do sangue que vertera da hóstia dera origem a duas novas crenças: "A crença na segunda Redenção, com suas implicações teológicas sofisticadas, enraizou-se sobretudo entre membros do clero e do laicato mais instruído. A crença no advento do milênio, intrinsecamente traumática, encontrava especial ressonância entre as massas supersticiosas e analfabetas" (Della Cava, I976: 62). E, contra essas crenças, segundo o autor, teria se posicionado a hierarquia da Igreja, à qual competia velar e manter a ortodoxia católica.

A interpretação que gostaria de levantar aqui vai noutra direção. Como venho argumentando, a expectativa da segunda vinda de Cristo não se reveste de novidade para o catolicismo popular tradicional. A iminência do fim do mundo está no cerne da escatologia bíblica e profundamente enraizada na cultura bíblico-católica dos sertões, partilhada de um modo geral pelos fiéis e pelo clero antes da romanização. Assim, se é verdade, como argumenta Della Cava (I976: 62), que a "situação política nacional parecia muito propícia à divulgação das duas novas crenças que começam a emanar de Juazeiro", também é verdade que os séculos XIX e XX estão marcados por uma profusão de milagres, oficialmente atestados e difundidos pela Igreja católica, como armas contra o modernismo e o racionalismo.

O fim do mundo é, assim, acionado pelos protagonistas das duas vertentes do catolicismo. Ou seja, na interpretação que estou esboçando aqui, não se trata de uma controvérsia teológica ou dogmática, como afirma Della Cava, mas de uma luta de poder entre os agentes, leigos e padres, do catolicismo popular e o clero reformador. E isso se torna mais evidente não só pela recusa do bispo em reconhecer o milagre, mas também pela imposição aos padres, que haviam acreditado e difundido o milagre, a se retratar publicamente, sob a ameaça de suspensão de ordens e destituição de seus cargos. Como era do conhecimento do bispo e recorrente na tradição católica, eventos semelhantes 
ocorridos na Europa, em que a hóstia vertera sangue na boca de sacerdotes e fiéis, são reconhecidos e difundidos pela Igreja no mesmo período histórico. ${ }^{\text {I2 }}$

Um olhar retrospectivo para os conflitos que ocorreram no Juazeiro permite-nos perceber que a intransigência da hierarquia eclesiástica em relação ao padre Cícero era, na verdade, a outra face da sua intransigência em relação à cultura católica popular. Os reformadores viam-se, nesse momento, como portadores de uma verdade elaborada nos círculos hierárquicos do poder que tinham em Roma o seu centro, para os quais a experiência e a prática de 400 anos do catolicismo no Novo Mundo não tinham a menor relevância. A reforma que eles propõem desconsiderava, portanto, qualquer valor de verdade ou racionalidade às práticas do catolicismo popular. Ou seja, não cabia mediação entre a verdade que portavam e o catolicismo vivido nos sertões. $O$ sentimento de cruzada, que impregnava o movimento romanizador, transformou as práticas, os rituais e as devoções dos pobres e peregrinos dos sertões numa nova heresia a ser erradicada. Produz-se, assim, uma dissociação entre a mensagem proclamada dos púlpitos e o catolicismo dos sertanejos, vivido em estreita relação com o ambiente e suas condições sociais de existência.

\section{OS INTELECTUAIS E A RECONCILIAÇÃo}

A mesma externalidade que observamos no clero romanizador em relação ao catolicismo dos sertanejos vamos encontrar nos intelectuais liberais em relação à cultura popular. Eles também se situam do lado de fora da cultura popular, como observadores, demarcando os limites entre um sistema tradicional e outro moderno adveniente. Esse modo de proceder, assumido em nome da verdadeira religião, por parte do clero, e da ciência, por parte dos intelectuais, está na origem da (di)visão dualista do país, que se aprofundou nesse momento de nossa história. A ideia de "dois brasis", que se confrontam, torna-se recorrente no discurso do clero e dos intelectuais liberais. Mas, ao mesmo tempo em que se produz a dualidade, como diferença cultural, produzem-se os discursos sobre a cidadania e os direitos sociais. Neste país, pensado estruturalmente como dual, a cidadania e os direitos tornam-se prerrogativas de poucos, em detrimento de uma maioria que, excluída do projeto moderno, passa a ser responsabilizada pela subalternidade da nação brasileira em relação aos países centrais.

Para demonstrar essa premissa, sigo a sugestão de Antônio Braga de revisitar o texto do educador paulista Manoel Lourenço Filho, inicialmente apresentado na forma de artigos para o jornal O Estado de São Paulo, entre novembro de I925 e agosto de I926, e posteriormente compilado no livro Joaseiro do Padre Cícero: cenas e quadros do fanatismo no Nordeste (Braga, 2008: 236). ${ }^{\mathrm{r} 3} \mathrm{~A}$ referência a esse texto permite-nos estabelecer um paralelo entre dois personagens centrais da primeira metade do século $\mathrm{XX}$, que foram posicionados, de uma forma emblemática, em campos de forças opostos. Como Braga nos mostra, Lourenço Filho representava o principal grupo de intelectuais da época, que 
escrevia em jornais e difundia, na opinião pública, o projeto moderno liberal de reformas na educação e na cultura, vistas como indispensáveis para a superação do atraso histórico do país e a modernização da sociedade. No jogo político especular de imagens invertidas, padre Cícero será identificado como mais um líder de fanáticos e incultos que resiste ao projeto modernizador.

Lourenço Filho visita o Juazeiro entre abril de I922 e dezembro de I923, período em que morou no Ceará. A visita foi motivada pela "resistência de Padre Cícero ao recenseamento das crianças de seis a doze anos que a Diretoria de Instrução Pública do Governo do Ceará pretendia realizar" (Braga, 2008: 235). Ainda que, aos olhos de Lourenço Filho, esta recusa do padre Cícero venha a compor mais uma "cena do fanatismo nordestino", expresso no subtítulo de seu livro, é possível fazer outra leitura desse fato, consoante com a lógica e a perspectiva da cultura popular. Ou seja, acreditamos que essa recusa do padre Cícero possa ser interpretada como uma atitude de resistência à dominação e ao controle do Estado sobre a vida da população local. Afinal, no contexto da cultura bíblico-católica dos sertões, qualquer recenseamento remete tanto ao decreto do imperador romano, que obrigou José e Maria a deslocar-se para Belém, onde Jesus nasceria numa manjedoura, quanto à subsequente matança de crianças, decretada por Herodes. ${ }^{14}$ Esse pré-texto, subjacente ao ato político de recusa ao recenseamento, poderia indicar, em vez de uma atitude obscurantista do padre Cícero, como foi vista por Lourenço Filho (2002), uma sintonia fina com a cultura dos sertanejos.

Impõe-se, aqui, a citação de um recorte, ainda que breve, da descrição que Lourenço Filho faz do seu encontro com o padre Cícero, no momento em que o patriarca recebia os romeiros em frente à sua casa.

\footnotetext{
O padre mal distingue, naquele tumultuar, o que todos se esforçam por dizer-lhe, e contenta-se em receber as espórtulas, os mimos singelos ou valiosos, os rosários, medalhas e bentinhos... Aos mais próximos, que lhe renteiam as faces, exibindo por vezes chagas sangrentas, ou os lábios comidos pela bouba, ou as faces maceradas pelo jejum, os olhos desfigurados pelo tracoma, ele receita... [...]. Algumas vezes distribui esmolas. Contudo, mais recebe que dá. E... quando se sente fatigado, quando as mãos em súplica já avançam pelas frestas da janela, e o atingem na sotaina, nos braços ou no peito, e já o empurram, violentas e ameaçadoras, ele, por sua vez, levanta a destra, como sinal de silêncio, sustenta-a no ar, por um instante, os olhos postos no céu, reverentemente, e desce, enfim, sobre aquela miséria e degradação, a bênção que a todos, indistintamente, consola e aplaca... Depois do que, aferrolhada por prudência a janela, lava as mãos, tranquilo e satisfeito, e vai merendar (Lourenço Filho, 2002: 55).
}

Seria necessário um longo e cuidadoso trabalho de interpretação do discurso para revelar o que está implícito no estilo que o autor imprime em sua descrição. Na verdade, ao longo de todo o livro, Lourenço Filho usa a linguagem literária e jornalística para exotizar o sertanejo com o intuito de produzir a diferença. Os romeiros aparecem, em sua narrativa, como tipos degradados, do- 
entes e degenerados que oscilam entre a submissão e a violência latente que ameaça a ordem. Seu texto produz o sertanejo como um "outro", cujo destino é o de ser absorvido numa nova ordem social e política, que deverá emergir da purificação cultural. O tom dramático do seu relato, ao mesmo tempo em que imprime realismo à cena descrita, também representa o romeiro como um outro incômodo, do qual devemos nos envergonhar. Talvez pudéssemos aplicar a Lourenço Filho a crítica que Lévi-Strauss (I944: 396) faz aos intelectuais brasileiros, que, deslumbrados com "as conquistas da civilização industrial", estariam apenas "simulando sofisticação para escapar do seu próprio destino nacional".

Ao produzir a alteridade, o encontro dos intelectuais com o sertanejo será, necessariamente, mediado pela narrativa moral que está impregnada da missão de purificar a cultura popular. É importante reter aqui o fato de que, embora os intelectuais se posicionem a favor da laicidade e da liberdade religiosa, o discurso moral que acionam, em nome do Estado, torna-se um instrumento de regulação do religioso, que acaba por negar o direito de expressão às formas tradicionais de religiosidade. Nesse sentido, a atitude de acolhida e respeito de padre Cícero para com os pobres do sertão torna-se altamente perturbadora, posto que evidencia um dissenso inoportuno na elite escolarizada. Afinal, o esperado da parte de um sacerdote católico, com formação escolar no nível daquela dos intelectuais, era que olhasse para os sertanejos como objetos da ação civilizadora do Estado e da Igreja. Ao contrário disso, seguindo o conselho de Lévi-Strauss (I944: 396), padre Cícero não se envergonha dos pobres do sertão, mas, ao contrário, opta por viver no meio deles, "para deles cuidar e amar com a maior paciência e compreensão".

Como um contraponto ao relato do encontro de Lourenço Filho com o padre Cícero, transcrevo o depoimento, registrado por Luitgarde Cavalcanti Barros (2008), do botânico alemão Philipp Von Luetzelburg que, a serviço da Inspetoria Federal de Obras Contra as Secas, esteve em Juazeiro em I92 I, apenas um ano antes da visita de Lourenço Filho.

Naturalmente, para mim [Von Luetzelburg], se tornou de capital importância conhecer e falar com o Padre Cícero e tive o prazer de, à minha chegada, ser recebido e ter uma animada palestra com o mesmo. Este velho, de real prestígio popular, deixou-me gratas recordações. Tratou-me com delicadeza e amabilidade. De fato, trata-se de um homem que dispõe de instrução e saber invulgares: aborda com igual facilidade a política, a história universal, as ciências naturais, especialmente quanto à agricultura. Os institutos científicos deveriam entrar em contato com aquele homem que dispõe de conhecimentos excepcionais com relação à Paleontologia, Geologia e História, adquiridos parte por observação e estudos pessoais, parte pelas indicações que colhe de seus inúmeros fiéis e romeiros, que, das paragens mais longínquas, trazem ao "Padrinho" tudo aquilo que encontram de esquisito e extraordinário... Poderia o leitor objetar que pouca importância se deve dar aos achados dos romeiros, geralmente sem instrução. Contudo, devo notar que tive oportunidade de estudar a curiosa coleção do Padre Cícero, onde encontrei material preciosíssimo (Barros, 2008:I89-I9o). 
O objetivo de trazer esse depoimento é mostrar ao leitor o caráter particular da posição de Lourenço Filho sobre o padre Cícero. A ênfase nesse ponto se faz necessária, uma vez que, como afirma Antônio Braga (2008: 235-236), "esta foi a obra literária que mais contribuiu - dado seu impacto e sua reverberação - para difundir, no imaginário nacional, Juazeiro, Padre Cícero e seus romeiros como a representação do atraso, da ignorância e da insanidade do fanatismo religioso que havia na sociedade brasileira. As mesmas pessoas que padre Cícero vê como amigas e afilhadas, Lourenço Filho descreve como ignorantes e supersticiosas. Seu discurso aprofunda, justifica e dissemina a ruptura e o preconceito.

Queremos esclarecer, aqui, que outras imagens e experiências positivas de encontro com padre Cícero e com o Juazeiro foram vividas e relatadas por intelectuais e cientistas da época. Ou seja, longe da imagem grotesca que Lourenço Filho apresenta do padre Cícero, aqueles que dele se aproximaram, sem a ideologia que se alimentava da divisão entre o Brasil atrasado dos sertões e o país do futuro que se anunciava, puderam testemunhar que, embora tenha vivido no sertão, sua visão do mundo e seu conhecimento tornavam-no um interlocutor capaz de dialogar com inteligência sobre questões e temas científicos e políticos da época. E, se sua formação no seminário lhe dera acesso a recursos que lhe conferiram um lugar entre os intelectuais, a sua vida e a sua posição política foram forjadas no convívio cotidiano com o sofrimento e estilo de vida dos romeiros. E, as poucas vezes que deixou Juazeiro, ele o fez como romeiro, para promover a reconciliação. Assim foi quando viajou a Roma, para advogar a favor de sua plena reintegração à Igreja, que o havia suspendido das ordens sacerdotais (Della Cava I976: I4I). Em sentido inverso, Lourenço Filho tem um interesse distanciado em relação ao padre Cícero e aos seus romeiros. Quando viaja ao sertão, o faz para comprovar sua tese sobre a incomensurabilidade entre o sertão pobre e atrasado e projeto de futuro de uma nova ordem a ser instaurada da qual ele se apresenta como arauto e propagador.

\section{CONCLUSÃo}

Ao longo deste texto, seguimos a linha da reconciliação para compreender a ação do padre Cícero como mediador entre o sertão e o litoral, entre os pobres e as elites nacionais, entre a cultura popular e a modernidade adveniente, entre o catolicismo tradicional e o movimento reformador. Uma ação que se torna particularmente agonística, visto que acontece num momento histórico em que essas divisões eram explicitadas e aprofundadas pelo projeto de modernização hegemônico que se afirmava com a proclamação da república e com o avanço do catolicismo ultramontano no país. E, nesse percurso, partimos de uma breve referência às raízes bíblicas do conceito de reconciliação, num esforço por estabelecer um diálogo das ciências sociais com a teologia. 
Em seguida, ainda na chave da interdisciplinaridade, incursionamos pela inesperada reflexão da filósofa judia Hannah Arendt sobre o perdão, como uma prática inaugurada por Jesus de Nazaré. Na esteira do que ela propõe, procuramos transpor os conceitos da reconciliação e do perdão do contexto religioso para a cena política, numa aposta de que eles nos dariam pistas preciosas para uma compreensão mais aprofundada dos fatos sociais que pretendíamos analisar. Ao puxar esse fio, foi possível perceber que a reconciliação não começa nem termina num decreto ou documento emitido por uma autoridade, mas ela permeia a totalidade da vida social e política, indo muito além dos cânones jurídicos e eclesiásticos.

Ao nos voltar mais especificamente para a prática pastoral e política do padre Cícero, demo-nos conta de que a reconciliação era o impulso vital que efetivamente o mobilizava. Então, discorremos sobre algumas controvérsias públicas em que ele esteve envolvido. E, ao analisar o sentido de sua mediação nesses conflitos, percebemos que ela foi exercida sempre em favor dos pobres e dos romeiros dos sertões. Ou seja, padre Cícero não foi um mediador neutro. Sua posição como sacerdote e intelectual conferiu-lhe um lugar de reconhecimento e legitimidade, o qual ele ocupou para falar em nome daqueles com os quais partilhava sua vida, morando e atuando como um pároco de aldeia, num rincão perdido do Nordeste, onde sua presença fez diferença, projetando-o no cenário nacional e internacional.

Ainda que a sociologia sobre o catolicismo milenarista tenha aproximado padre Cícero de Antônio Conselheiro e de João Maria, mostramos que a reconciliação, como valor fundante da ação do padre Cícero, demarca uma diferença substantiva entre eles. Ou seja, padre Cícero não se posiciona contra as promessas dos avanços tecnológicos, sociais, morais e políticos da modernidade. Ao contrário, ele foi um agente de modernização em Juazeiro. Sua crítica, na verdade, se direciona ao projeto de modernização, posto em curso pelas elites política e pelos intelectuais liberais, uma vez que excluía os pobres do sertão e os apresentava como um entrave a ser removido no caminho do progresso que o Brasil deveria trilhar, tendo como modelo os países desenvolvidos.

Por fim, entendemos que a crítica do padre Cícero aos projetos hegemônicos de modernização da sociedade brasileira e de reforma do catolicismo romano tem como foco o fato de eles excluírem os pobres e negarem a cultura e a religiosidade como dimensões a incorporar na narrativa da nação - o que fica evidente, como argumentamos recorrendo a Lévi-Strauss, na vergonha que os intelectuais liberais e o clero ultramontano deixam transparecer em relação aos "aspectos primitivos, os pontos mais feios" da cultura popular, incapazes de reconhecer que "o sertanejo é, antes de tudo, um forte", como o fez Euclides da Cunha, na frase que se tornou um ícone da literatura brasileira. Ao contrário, padre Cícero nunca se envergonhou de seu povo e, em fina sintonia com os valores e as crenças que teciam a sua cultura e religiosidade, olhava com profunda 
desconfiança para o projeto de modernização que tinha como horizonte o desencantamento do mundo e a erradicação da cultura e da religiosidade popular. Mesmo porque, para qualquer sujeito que, como ele, vivesse imerso no ambiente do sertão seria impossível imaginar um mundo fora da cultura popular e da religiosidade católica.

Recebido em I8/I I/20I9 | Revisto em 02/04/2020 | Aprovado em I2/05/2020

Carlos Alberto Steil é doutor em antropologia social pelo Museu Nacional/UFRJ. Professor titular na Universidade Federal do Rio Grande do Sul, professor-visitante na Universidade Federal de São Paulo e pesquisador do CNPq. Realizou pós-doutorado na Universidade da Califórnia, San Diego, foi presidente da Associação de Cientistas Sociais do Mercosul, diretor da Associação Brasileira de Antropologia, coordenador da Área de Antropologia e Arqueologia da Capes e do Núcleo de Estudos da Religião, e editor das revistas Horizontes Antropológicos, Ciencias Sociales y Religión e Debates do NER. Tem pesquisado temas como peregrinação, turismo, catolicismo, Nova Era. Dentre suas publicações destacam-se O sertão das romarias (Prêmio Sílvio Romero) e, em coautoria, On the nature trail, bem como a organização, com diversos colegas, de coletâneas como, por exemplo, Entre trópicos, além de artigos em periódicos científicos e capítulos de livros. 


\section{NOTAS}

I A questão da reconciliação, como mostra Pierre Sanchis (2007: I2), coloca-se como central nos acontecimentos de Juazeiro: "desde o início, o drama encenado em Juazeiro foi tripolar: Cícero, a Igreja, o Povo. E se este último polo foi sempre mantido na ambivalência, por causa da tensão entre os dois primeiros, parece despontar hoje uma inesperada resolução: no intuito não de reabilitar o Pe. Cícero, mas de operar a reconciliação da Igreja com ele, o bispo diocesano nomeou uma Comissão cujo trabalho históricoeclesial chegou a conclusões positivas".

2 Apresento aqui um resumo dos principais fatos que marcaram a trajetória do padre e que são referências para este texto. EmI889, padre Cícero testemunha o milagre da hóstia que verte sangue, durante a comunhão da beata Maria de Araújo. Em I894, a Santa Sé considera que houve fraude e reprova o milagre como "gravíssima e detestável irreverência e ímpio abuso à Santíssima Eucaristia”. Em I897, é emitida uma portaria de excomunhão, caso ele não se retire de Juazeiro. Em I898, depois de apresentar sua defesa em Roma, padre Cícero recebe uma nova sentença: é absolvido das censuras, mas fica proibido de falar ou escrever sobre o "milagre da hóstia". Em I922, um pedido de reabilitação é negado pelo papa Leão XIII. Em I926 ele é suspenso de ordens. Em I934, aos 90 anos, ele morre, sem ter conseguido a reconciliação com a Igreja. Em 200I, o bispo do Crato, dom Fernando Panico, a pedido de Roma, institui a Comissão de Reabilitação Histórica do Padre Cícero, formada por cientistas sociais, historiadores e teólogos para estudar os arquivos relativos aos fatos de Juazeiro. Em 2006, o resultado da análise da Comissão é entregue ao Vaticano, com petição, assinada por 254 bispos, para a reabilitação de Padre Cícero. Em 20I5, o secretário de Estado do Vaticano assina a carta de "reconciliação histórica da Igreja com o Padre Cícero"

3 Convém lembrar, aqui, que, enquanto o movimento civil se volta preferencialmente para os Estados Unidos, um país protestante e uma democracia liberal, o movimento eclesial volta-se para o continente europeu, de onde vem a maioria dos missionários das ordens religiosas modernas, impulsionadoras das transformações ultramontanas no catolicismo no Brasil. 
4 A noção de romanização do catolicismo brasileiro foi sugerida por Roger Bastide e desenvolvida por Ralph Della Cava (I970) e por Ribeiro de Oliveira (I985).

5 A questão religiosa ocorreu na década de 1870 , poucos anos antes da separação entre Igreja católica e Estado no Brasil. A crise teve origem nas interdições impostas pelos bispos dom Vital Gonçalves de Oliveira e dom Macedo Costa à presença de maçons em instituições religiosas, como as irmandades e na proibição do imperador à divulgação e implementação de resoluções papais no Brasil. O conflito resultou na prisão e condenação dos prelados por desobediência civil.

6 A Guerra de Canudos, liderada por Antônio Conselheiro, eclodiu na primeira metade do século XX, no estado da Bahia, no Nordeste brasileiro. Já a Guerra do Contestado, teve como protagonista o monge José Maria que, no início do século XX, reúne caboclos do Sul do país, nos estados do Paraná e de Santa Catarina. Esses dois movimentos enfrentaram as forças armadas do Exército brasileiro e terminaram em violentos massacres dos insurgentes.

7 Della Cava (I976) faz um balanço do progresso econômico e social que Juazeiro alcançou no período do padre Cícero, graças à introdução de novas técnicas agrícolas no campo e a promoção do artesanato e de pequenas indústrias na cidade. Juazeiro distingue-se, das demais localidades do Ceará e do Nordeste, mesmo num período de seca e crise que assolou a região nordestina.

8 Segundo Ralph Della Cava (1976: 33) "as transformações mais importantes nas estruturas religiosas do Cariri ocorreram na década de 1860/1870 e foram devidas, primordialmente, aos esforços de uma das personalidades mais conhecidas do Nordeste, o ardoroso missionário, nascido - Ceará, Padre Mestre Ibiapina".

9 A narrativa que transcrevemos aqui tem como base o relato do sonho apresentado por Della Cava (i976: 24) que, por sua vez, como o autor explicita em nota, se trata de uma paráfrase do que se encontra em carta de Pelúsio Correa de Macedo, de I955, registrada por Della Cava (I976: 4I) em documento de referência de sua pesquisa histórica e tem como referência uma versão anterior de Manuel Dinis, publicada em I935 (Della Cava, I976: 47). 
Io É preciso lembrar aqui que, tanto nos relatos bíblicos como na vida dos santos, há inúmeras recorrências à comunicação de Deus e dos mortos por meio de sonhos. Nesse sentido, recorrer a um sonho como referência para uma decisão não deveria ser estranho à cultura bíblico-católica predominante na época.

I I A controvérsia sobre o milagre do Juazeiro está amplamente analisada no livro de Ralph Della Cava (i976), cujos relatos históricos serviram de base para nossa reflexão e ao qual remetemos o leitor.

I2 O milagre mais antigo, na tradição católica, da transformação da hóstia em carne e do vinho em sangue, teria ocorrido no século VIII, na cidade italiana de Lanciano. Esse milagre foi oficialmente reconhecido pela Igreja católica como o milagre eucarístico de Lanciano. Os frades menores conventuais custodiam o local do milagre desde I252, por determinação de uma bula pontifícia. Outros milagres semelhantes são relatados até os dias de hoje. Um dos últimos teria ocorrido em I996, na cidade de Buenos Aires.

I3 A primeira edição do livro de Lourenço Filho foi publicada em I926 e, em I927, foi premiada pela Academia Brasileira de Letras. A edição mais recente foi publicada em 2002, pelo MEC/Inep, sem o subtítulo.

I4 A correspondência entre eventos históricos e mitos bíblicos, na tradição popular católica, foi referida por Victor Turner e Edith Turner (1978: 48): para os autores, essa correspondência remete a uma "raiz paradigmática" do mito bíblico, que opera como um meio pelo qual "os pobres e iletrados" conservam em sua memória as doutrinas e os dogmas católicos. Em O sertão das romarias (Steil, I996), tomo essa referência como um elemento a favor do argumento da existência de uma cultura bíblico-católica no sertão nordestino. Esse conceito tem sua origem na ideia de pré-texto, proposta por Otávio Velho (I987), em artigo sobre a besta-fera no qual elaborou a ideia de uma cultura bíblica.

\section{REFERÊNCIAS BIBLIOGRÁFICAS}

Arendt, Hannah. (1989). A condição humana. Rio de Janeiro: Forense Universitária. 
Barros, Luitgarde Oliveira Cavalcanti. (2008). Juazeiro do Padre Cícero: a terra da mãe de Deus, 2 ed. Fortaleza: Editora Imeph.

Bauer, Johannes. (2000). Dicionário bíblico-teológico. São Paulo: Loyola.

Braga, Antônio M. da Costa. (2008). Padre Cícero: sociologia de um padre, antropologia de um santo. Bauru: Edusc.

Della Cava, Ralph. (1976). Milagre em Joaseiro. Rio de Janeiro: Paz e Terra.

Lévi-Strauss, Claude. (1944). South America: rebellion on the backlands. American Anthropologist, 46/3, p. 394-396.

Lourenço Filho, Manoel Bergström. (2002). Juazeiro do Padre Cícero. Brasília: MEC/Inep.

Oliveira, Pedro Ribeiro de. (1985). Religião e dominação de classe: Gênese, estrutura e função do catolicismo romanizado no Brasil. Petrópolis: Vozes.

Sanchis, Pierre. (2007). Desponta novo ator no campo religioso brasileiro? O padre Cícero Romão Batista. Religião \& Sociedade, 27/2, p. II-29.

Steil, Carlos Alberto. (I996). O sertão das romarias: um estudo antropológico sobre o santuário de Bom Jesus da Lapa, Bahia. Petrópolis: Vozes.

Turner, Victor \& Turner, Edith. (1978). Image and pilmigrage in Christian culture. Oxford: Basil Blackwell.

Velho, Otávio. (1987). O cativeiro da besta-fera. Religião \& Sociedade. I4/I, p. 4-27. 


\section{Palavras-chave \\ Padre Cícero; \\ reconciliação; catolicismo; peregrinação; romanização.}

Keywords

Father Cícero; reconciliation; catholicism; pilgrimage; romanization.

\section{PADRE CÍCERO: RECONCILIAÇÃO E MODERNIDADE}

\section{Resumo}

O presente artigo tem como foco o sentido da reconciliação na ação política do padre Cícero Romão Batista. Partindo dos contextos teológico e filosófico em que surge o conceito, interpreta-o, à luz das ciências sociais, como um divisor de águas entre dois projetos de nação que atravessam a história recente do país. De um lado, o projeto excludente, que afirma e reproduz a divisão, defendido pelas elites políticas, pelos intelectuais liberais e pelo clero reformador. Do outro, o projeto inclusivo, defendido pelo padre Cícero, para quem, a realização da modernidade dependeria da reconciliação entre tradição e modernidade. A base de referência empírica para o argumento é a revisão, nos anos 2000 , do processo de condenação do padre Cícero por parte da Igreja católica. O caminho trilhado foi o da pesquisa histórica, revisitando a literatura, reinterpretando as teses de alguns autores de referência que escreveram sobre o padre Cícero.

\section{PADRE CÍCERO: RECONCILIATION AND MODERNITY}

\section{Abstract}

This paper focuses on the sense of reconciliation in the political action of Father Cícero Romão Batista. Starting from the theological and philosophical contexts, in which the concept arises, we interpret it, in the light of the social sciences, as a watershed between two nation projects that go through the Brazilian recent history. On the one hand, the exclusionary project, which affirms and reproduces the division, advocated by political elites, liberal intellectuals, and the reforming clergy. On the other, the inclusive project, defended by Father Cícero, for whom, the realization of modernity would depend on the reconciliation between tradition and modernity. The empirical reference base for the argument is the review, in the 200os, of the process of condemnation of Father Cícero by the Catholic Church. The path followed was that of historical research, where we visited the literature, reinterpreting the theses of some authors of reference who wrote about Father Cícero. 